Anat. Histol. Embryol. 31, 37-51 (2002)

(C) 2002 Blackwell Wissenschafts-Verlag, Berlin

ISSN 0340-2096

Institut für Tieranatomie der Ludwig-Maximilians-Universität, München, Germany

\title{
Periods and Stages of the Prenatal Development of the Domestic Cat
}

\section{KNOSPE}

Address of author: Institut für Tieranatomie der Ludwig-Maximilians-Universität München Veterinärstrasse. 13, D-80539 München, Germany; e-mail: c.knospe@anat.vetmed.uni-muenchen.de

With 5 figures

Received February 2001; accepted for publication July 2001

\begin{abstract}
Summary
Twenty-two stages of the prenatal development of the domestic cat are described for intraspecies comparison in embryological studies. These are assigned to the 15 embryonal periods based on the Nomina Embryologica Veterinaria to make the interspecies comparison possible.
\end{abstract}

\section{Introduction}

The domestic cat is one of the main species used for experiments and in embryological studies today, because the diet, reproduction and general care of cats are well documented and easy to follow and their gestation is short (Scott, 1977).

In spite of our overall general knowledge on the subject, no comprehensive study and description of the developmental stages of the domestic cat has been done. Apart from the available information only a succinct and incomplete synopsis of references exists on the subject (Oppel, 1891; ZietzschmannKrölling, 1955; Evans and Sack, 197; Habermehl, 1975; Noden and DeLahunta, 1985; Schnorr, 1989; Rüsse and Sinowatz, 1991; Günther, 1994). None of these studies offers a useable staging or standardized periods according to the Nomina Embryologica Veterinaria (NEV; Frewein et al., 1994).

\section{Materials and Methods}

In addition to the references presented in the general outline, this study is based on our own findings from 126 cat embryos, and from 68 specimens and 52 sets of histological serial sections from the collection of the Institute of Veterinary Anatomy, Histology and Embryology of the Free University Berlin. Literature on postnatal development, the ultrastructure of different organs during development, and references without precise length or age estimations, were not considered for this study.

The precise age of the studied specimens was measured in hours (h) or days post coitum, which was observed in most of the cases. Size in early stages (1-12) was measured by recording the diameter or total length; the length of the older specimens (13-22) is given as crown-rump length (CRL), measured in mm along the back from the head to the breech, in accordance with the German measurement SSL (ScheitelSteiß-Länge).

Preparation, fixation, sectioning and staining procedures were different according to the descriptions of the Berlin Institute collection. Most of the specimens were Bouin fixed, standard Paraplast embedded, and serial sections were haematoxylin and eosin and trichrome stained, as were my own material. The older uncut specimens were fixed in $4 \%$ formalin. Stages are numbered and periods of the NEV are given in parenthesis.

\section{Results}

Between 20 and $28 \mathrm{~h}$ after mating the conceptus (Zygota) consisting of fertilized eggs of an average size of $0.13 \mathrm{~mm}$, could be flushed from the oviducts. This mirrors the majority of existing references (Longley, 1911; Manwell and Wickens, 1928; Greulich, 1934; Dawson and Kosters, 1944; Amoroso, 1952; Denker et al., 1978; McLaren, 1978, 1980; Günther, 1994; Wildt et al., 1998).

\section{Stage 1 (Blastogenesis): $2 \frac{1}{2}-4 \frac{1}{2}$ days}

The actual development starts with the division of the conceptus into the first two blastomeres $60-68 \mathrm{~h}$ post coitum. After this, the cell division of the blastomerula occurs every $10-14 \mathrm{~h}$, becoming rather quickly asynchronous. The diameter of the blastomeres decreases, but the diameter of the blastomerula inside the zona remains almost constant (Fig. 1). References differ here, giving the following findings: first division during $24 \mathrm{~h}$ (Günther, 1994), one to four cells after $64 \mathrm{~h}$, five to eight cells after $76 \mathrm{~h}$ (Swanson et al., 1994), two cells early in day 3, 16 cells at day 4 (Enders, 1970; Wild et al., 1998), four to eight cells on day 3 and 10-16 cells of two types at day 4 (Denker et al., 1978; Noden and DeLahunta, 1985).

\section{Stage 2 (Morulatio): 4 $1 / 2-6$ days}

During the morulation stage about 30 cells form a sphere, the morula, consisting of smaller dark and larger granulated, pale cells. The total diameter is almost the same (Fig. 2). In other references the morula of 24-40 cells was found in the oviduct between 72 and $124 \mathrm{~h}$ post coitum (Denker et al., 1978; Noden and DeLahunta, 1985; Schnorr, 1989; Swanson et al., 1994).

\section{Stage 3 (Blastulatio): 6-81/2 days}

With the formation of a cavity, surrounded by $60-80$ cells, the blastocyst of $0.6 \mathrm{~mm}$ in diameter develops, found in the uterus lumen after $140-150 \mathrm{~h}$. At day 8 , the blastocyst becomes ovoid by extending inside the zona. Only the embryoblast and the trophoblast are distinct inside, the outside already resembling the later gastrula (Fig. 3).

The literature describes the early blastocyst formed by 60-100 cells (Noden and DeLahunta, 1985; Schnorr, 1989), 
seen at $120 \mathrm{~h}$ (Takaya, 1989) to $148 \mathrm{~h}$ (Swanson et al., 1994) in the uterus lumen (Denker et al., 1978).

\section{Stage 4 (Gastrulatio): $81 / 2-101 / 2$ days}

During the delamination phase, the gastrula is characterized by the formation of the inner endodermal layer. The gastrula is about $1.5 \times 1 \mathrm{~mm}$, egg-shaped, with tall cells in the embryonic shield, without visible cover (Fig. 4). The literature describes a blastocyst with zona, with endoderm formation by delamination, $0.5-3 \mathrm{~mm}$ in size by 10 days in the preinvagination phase of gastrulation (Denker et al., 1978), and endoderm formation (Hill and Tribe, 1924).

\section{Stage 5 (Gastrulatio): 101/2-12 days}

In the following phase, the primitive streak stage, gastrulation leads to the formation of the mesodermal layer by invagination in the shield area, the primitive streak becomes visible, and later on the notochord is seen as a rod of condensed mesoderm extending as head processes from its anterior edge. The zona vanishes (Fig. 5). The literature describes the invagination phase of gastrulation, the appearance of the primitive streak and primitive pit and the formation of the mesoderm (Denker et al., 1978).

\section{Stage 6 (Periodus sulci neuralis initialis): 12-13 days}

During the neurulation stage, the neural plate, and later the neural folds with the neural groove, are developing over the notochord of the neurula (Fig. 6). The literature decribes a size of $2 \times 1.5 \mathrm{~mm}$, zona disintegration (Denker et al., 1978), free blastocyst (Murray, 1951), and growth of the notochord from the primitive node (Günther, 1994).

\section{Stage 7 (Periodus mesodermalis et mesenchymalis): 13-14 days} As the notochord of the coelomatula elongates in the mesodermal stage, the paraxial mesoderm starts the formation of somites. The lateral plates remain unsegmented, but form the lining of the coelom. Head and tail folds develop and bulge slightly into the open amniotic cavity. Total size is $2 \times 3 \mathrm{~mm}$, and the huge vacuolated trophoblast starts to contact the uterus epithelium (Fig. 7). The literature describes the beginning of implantation (Leiser, 1979), fruit chambers of the uterus $9-10 \mathrm{~cm}$ in diameter (Courrier and Gros, 1935), somite formation (Evans and Sack, 1973), size $4 \times 2 \mathrm{~mm}$, five pairs of somites, neural plate (Halley, 1955; Denker et al., 1978), 3-7 $\mathrm{mm}$, start of neurulation, first somites, implantation between 12 and 14 days (Günther, 1994), and neural crest and first head ganglia (Martin, 1890b; 1891a).

\section{Stage 8 (Periodus sulci neuralis maturi et somitorum immaturorum): 14-15 days}

The metamerula of the somite stage already shows six to eight somites, the head and tail folds are much more prominent, the left and right primitive aorta and endocardial tubes are visible. The head contains three brain vesicles, the forebrain with optic vesicles. Otic, optic, olfactory and hypophyseal placodes are distinct. Under the head fold the stomatodaeum is separated from the foregut by the buccopharyngeal membrane, bounded on either side by the developing first pharyngeal arch. The closure of the neural folds has progressed cranially, but the neuropores are still open. On both sides the neural crests are seen, and caudally the tail bud. The midgut and yolk sac are open, haematopoiesis is occurring in the yolk sac and implantation starts (Fig. 8). According to the literature: $6 \times 5.5 \mathrm{~mm}$ embryo, start of implantation (Murray, 1951; Denker et al., 1978; Schnorr, 1989), optic vesicles, otic placode, neural tube, eight somites (Evans and Sack, 1973), 7-14 somites, formation of the head fold, forebrain ventral, trigeminal neural crest expands from the rostrum to the optic vesicles, the acousticofacial neural crest is under the otic placode and behind this is material of the vagoglossopharyngeal crest (Halley, 1955), haematopoiesis in the yolk sac (van Ooyen, 1977), neurulation (Noden and DeLahunta, 1985; Schnorr, 1989), start of neural fold closure (Günther, 1994), otic vesicles and ganglia of the cranial nerves developing (Martin, 1890b; 1891a), $3 \mathrm{~mm}$, unfused heart primordium, aortic arch, dorsal aorta, two pharyngeal arches, buccopharyngeal membrane intact (Coulter, 1909; Schulte, 1916), pronephros developing near the somites, which form cavities (Fraser, 1920).

\section{Stage 9 (Periodus tubi neuralis): 15-17 days, 2-10 mm}

The neural tube stage, called tubula, is characterized by a closed neural tube flanked by $15-18$ somites. Only the caudal neuropore is still open. Near the rhombencephalon, otic vesicles and organized neural crest material are visible. The head is prominent, covered by the developing amnion fold and slightly turned against the caudal body parts. Two pharyngeal arches, auditory pits, optic vesicles with stalk, Rathke's pouch in the stomatodaeum, heart with pericardial swelling, bulbus cordis, ventral aorta, cardinal- and omphalomesenterical venes are distinct. The midgut is open, the hindgut is covered by the cloacal membrane, the pronephros is expanding and the placental girdle is developing (Fig. 9). Literature descriptions include: three pharyngeal arches, 20 somites, caudal rotated (Evans and Sack, 1973), cervical flexure of the neural tube, pharyngeal ectodermal grooves, dorsal of the first arch the trigeminus placode, dorsal of the second arch in front of the otic vesicle the acoustico-facial placode and behind that the vago-glossopharyngeal placode (Halley, 1955), 10 somites (Noden and DeLahunta, 1985), hypophyseal primordium (Brahms, 1932; Gilbert, 1934), hollow optic vesicle stalk (Martin, 1890a), three pharyngeal arches, bulbus, three pairs of brachial arteries, five pharyngeal pouches (Coulter, 1909), late neurula with the formation of brain vesicles, heart loop, foregut, midgut, hindgut (Günther, 1994), laryngotracheal groove (Glöckel, 1984), pro- and mesonephros from segment 10-15 (Tiedemann, 1976b), pronephros from somite 8-14, developing pronephritic duct (Fraser, 1920), yolk sac placenta and peripheral paraplacental haematoma (Rüsse and Sinowatz, 1991).

\section{Stage 10 (Periodus pharyngealis initialis): 16-18 days, 3-14 mm}

The body of the branchiomerula is turned, three pharyngeal arches, pouches and clefts are distinct. The first arch with maxillary and mandibular processes bounds the stomatodaeum. Cranial and cervical flexures curve the head with the telencephalon and diencephalon, midbrain and hindbrain. The anterior neuropore is closed and the optic vesicles are stalked, the lens 


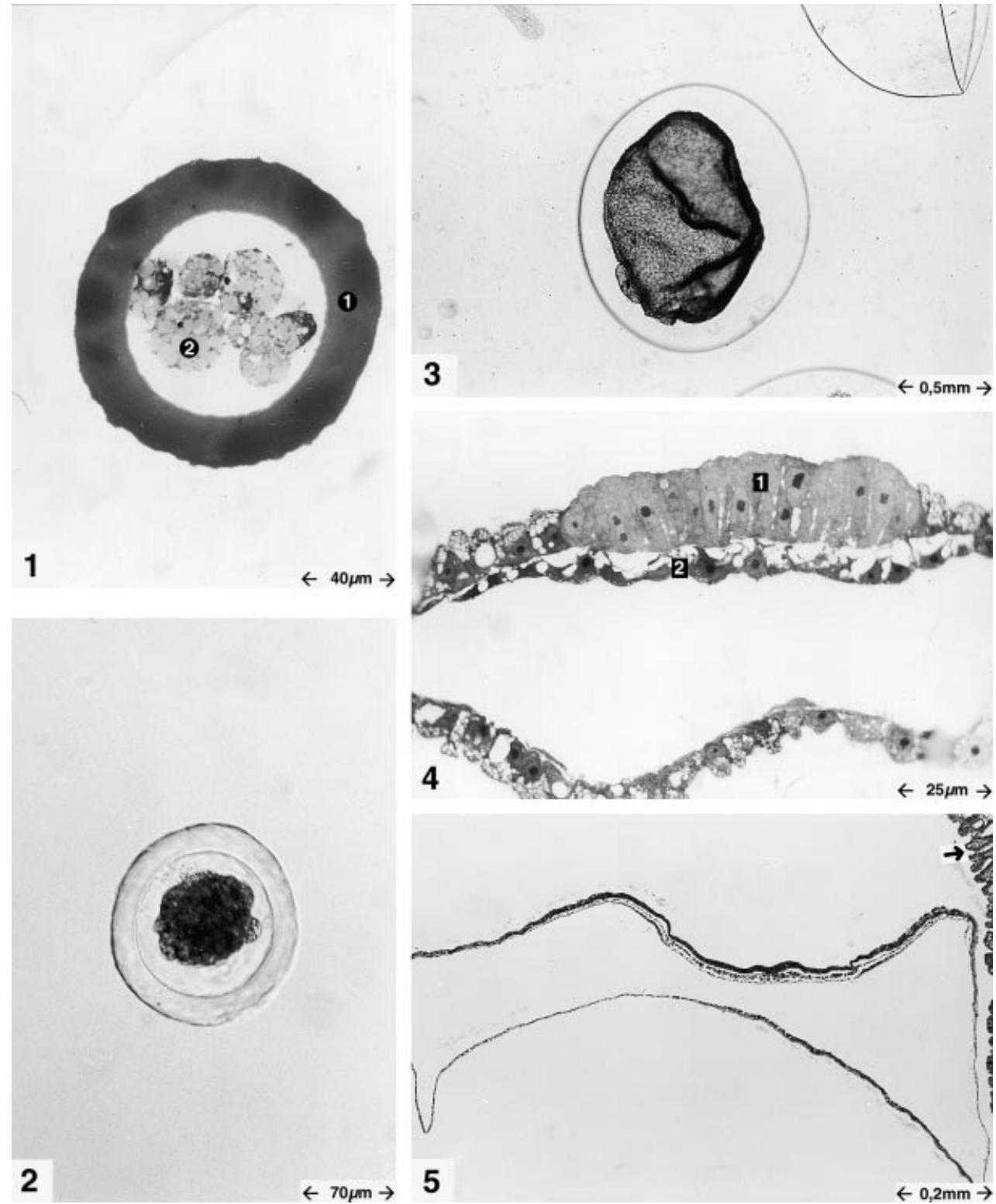

Fig. 1. Stage 1: late blastomerula, $4 \frac{1}{2}$ days. $1=$ zona; $2=$ blastomeres.

Fig. 2. Stage 2: late morula, 6 days.

Fig. 3. Stage 3: late blastocyst, 8 days, with an ovoid zona.

Fig. 4. Stage 4: early gastrula, 10 days. $1=$ embryonic disc ectoderm; $2=$ endoderm.

Fig. 5. Stage 5: late gastrula, 12 days, composed of three layers. $=>$ endometrium.

placodes are formed. Dorsal from the auditory pit and the hyoid arch is the hindbrain with a thin cover. The trunk already has 25-30 somites, it is open ventrally, but the connection between midgut and yolk sac has become constricted and is surrounded by the intra- and extra-embryonic coelom. The heart inside the pericardial swelling is just under the primitive pharynx and the laryngotracheal groove. It is S-shaped, and the atrioventricular canal is constricted. Behind the heart, the liver blasteme is developing in the septum transversum. In the bended caudal part, the pro- and mesonephros are enlarged (Fig. 10). Literature descriptions include: $5 \mathrm{~mm}$ CRL, two branchial arches, cervical sinus, hindbrain with trigeminus blasteme, caudal the cranial nerves VII-X and the epibrachial placodes (Halley, 1955), segmented parachordal plate and head somitomeres (Kernan, 1916; Terry, 1917), brachial artery 1-2 reduced, 3, 4 and 6 distinct (Coulter, 1909), 4 mm CRL (Noden and DeLahunta, 1985), 7-15 mm, two pharyngeal arches, cranial neuropore narrow, optic vesicles, otic placode and stomatodaeum developed, inside pronephros and laryngotracheal groove (Günther, 1994), 17 days, 9-11 segments, between segment 11-21 the mesonephros with Wolff's duct (Tiedemann, 1976b), the pronephros is already reduced, the mesonephros develops caudal of segment 11 (Fraser, 1920).

Stage 11 (Periodus pharyngealis ultima): 17-18 days, 5-16 mm

The pharyngula shows four pharyngeal arches, the first with prominent maxillary and mandibular processes, the second elongated direct above the pericardial swelling. The head is markedly flexed on the trunk at the cervical flexure and the tip 

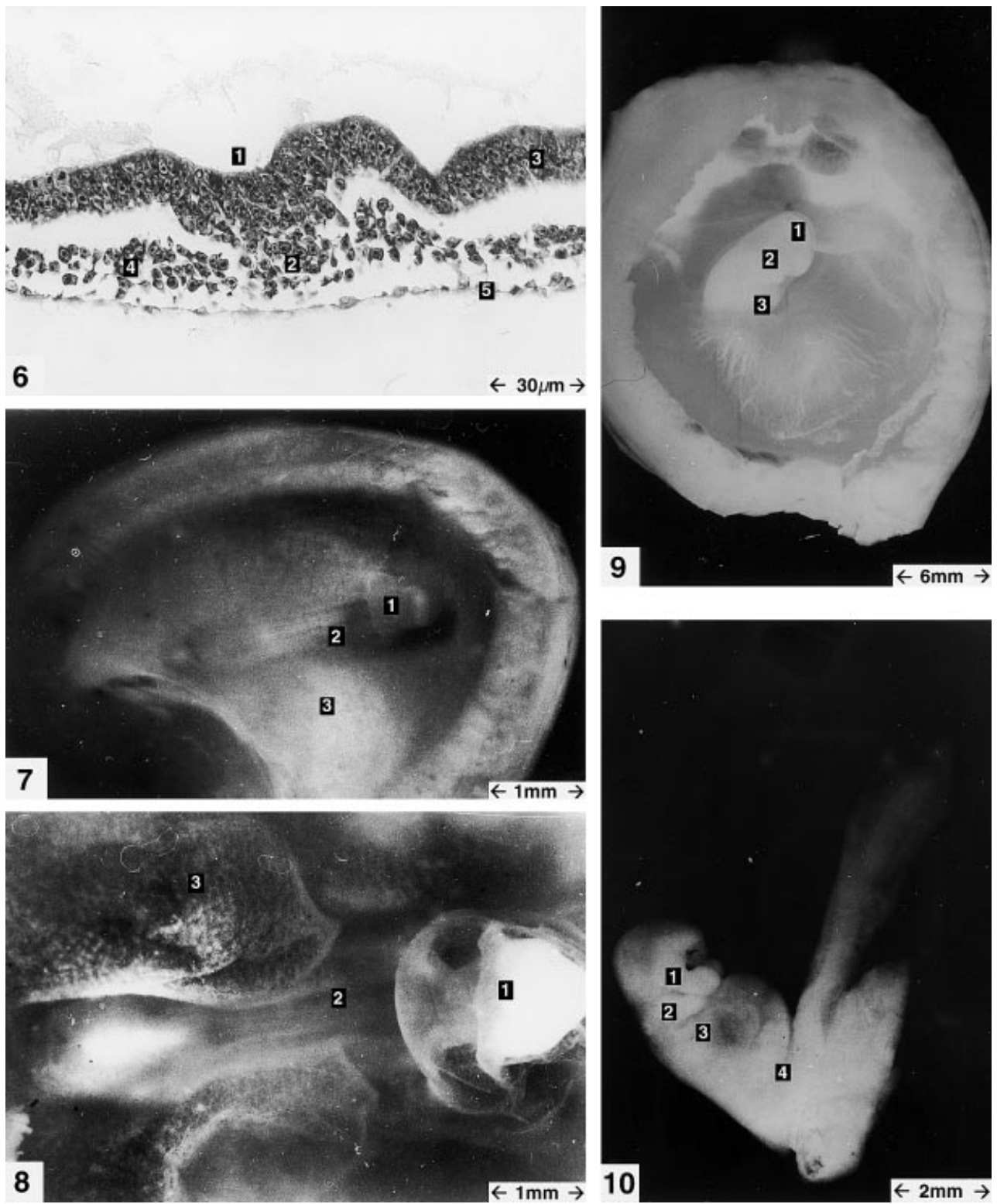

Fig. 6. Stage 6: neurula, 13 days. $1=$ neural groove; $2=$ notochord; $3=$ ectoderm; $4=$ mesoderm; $5=$ endoderm

Fig. 7. Stage 7: coelomatula, 14 days. $1=$ head fold; $2=$ first somites; $3=$ trophoblast

Fig. 8. Stage 8 : metamerula, 15 days. $1=$ head with brain vesicles; $2=$ somites over the primitive gut; $3=$ yolk sac.

Fig. 9. Stage 9: tubula, 17 days. $1=$ head with amnion; $2=$ first pharyngeal arches underneath the rhombencephalic vesicle; $3=$ heart.

Fig. 10. Stage 10: branchiomerula, 18 days. $1=$ first pharyngeal arch bounding the stomatodaeum; $2=$ second arch under the otic vesicle; $3=$ third arch above the heart; $4=$ caudal body part turned

of the head region, with a prominent frontal process and the olfactory placodes, is bent towards the pericardium. The auditory pits, lens pits and optic cups are well established. Inside can be found four pharyngeal pouches with thickened epithelium, five branchial arteries, the primitive pharynx is now opened to the stomatodaeum and over the truncus arteriosus the thyroid primordium is invaginated and behind two lung vesicles are distinct. From the outside, 30-40 somites are visible and behind heart and liver the forelimb buds appear between somite $8-12$. The caudal part and the tail are curved, the caudal neuropore is still open, but the attachments of the yolk sac and amnion are reduced on the ventral aspect to form an umbilicus and umbilical cord. Inside the liver is grown, the pancreas invaginated and the pro- and mesonephros enlarged from segment 11-27 (Fig. 11). Literature descriptions include: 7-8 mm CRL, four branchial arches, clefts, cervical sinus, the material for the cranial nerves is separated (Halley, 1955), branchial arteries are elongated, the embryo is $10 \mathrm{~mm}$ (Coulter, 1909), Rathke's pouch is visible (Gilbert, 1934), first appearance of pigment in the retina (Martin, 1890a, 1891b), lens pit distinct (Gilbert, 1947), $6.3 \mathrm{~mm}$ and $0.0078 \mathrm{~g}$ (Tiedemann and Ooyen, 1978), haematopoiesis in the yolk sac (Tiedemann, 1976a; Ooyen, 1977), first muscle blastemes (Trnkova-Hergetova and Dylevsky, 1994), four pharyngeal arches, the first divided, otic and olfactory pits visible, forelimb bud is seen behind the heart. Inside Rathke's pouch, thyroid, lung vesicles and stomach are visible (Günther, 1994), oesophagus and stomach anlagen visible (Bremer, 1992), the 
mesonephros reaches at day 18 (37 somites) the 28th segment, each segment with two or three S-shaped canaliculi (Tiedemann, 1976b).

\section{Stage 12 (Periodus gemmarum membrorum initialis): 18-19 days, 7-18 mm}

At the gemmula, paired paddle-shaped forelimb and shallow hindlimb buds make their appearance. The cervical flexure is still accentuated, but now also trunk and tail are flexed. Foreand midbrain are marked, the hindbrain shows the pontine flexure and the otic vesicle, ventral of it. The optic cup with the lens pit is above the fusion line of maxillary process and lateral nasal fold. Olfactory pits are visible on the head above the stomatodaeum. The hyoid arch overlaps the third arch with the operculum to enclose the cervical sinus. The trunk is well established with heart, liver and mesonephritic swelling, somites can still be recognized although they are already in differentiation (Fig. 12). Literature descriptions include: 5-8 $\mathrm{mm}$, forelimb bud, olfactory placodes (Evans and Sack, 1973), $8 \mathrm{~mm}$, lens and optic cup (Gilbert, 1947), start of retina differentiation (Martin, 1890a, 1891b), aortic and carotid arch dorsal still connected (Coulter, 1909), all parts of the hypophysis set up (Brahms, 1932), formation of the cervical sinus, rotation of the embryo, hindlimb bud near the tail bud, lens and olfactory pit visible, head flexures and mesonephritic swelling distinct, forelimb bud paddle-shaped, mesonephros up to the 27th segment, pancreas lobulated (Günther, 1994), genital ridge ventromedial of the mesonephros (Sainmont, 1906).

\section{Stage 13 (Periodus gemmarum membrorum initialis): \\ 19-21 days, 10-24 mm (CRL)}

The cervical flexure is rectangular in the auricula, the cervical sinus nearly closed and the first pharyngeal groove has deepened to form the external auditory meatus. It is rounded by small ear tuberculi. The optic cup with the fissura chorioidea is clearly pigmented and the olfactory pits are deepened to the primitive nasal cavity. The hindbrain is divided by a prominent pontine flexure. The upper limb is now subdivided into arm, forearm and hand with an inner mesenchymal skeleton, while the hindlimb still retains its primitive paddle-shape. Somite counting no longer precise, because the cranial somites vanish. The tail is elongated and curled. Inside the branchial arteries and nerves are going to differentiate, the thyroid is lobated and contacts the parathyroids and thymic primordia, the thyroglossal duct is elongated. Further differentiation of heart and blood vessels takes place. Larynx, trachea and the paired lung primordia are distinct and also stomach, oesophagus, intestine, dorsal and ventral pancreas primordia. In the liver the sinusoids, portal vein and gall bladder are seen. Dorsally, the primitive vertebrae are formed around remnants of the notochord. The primitive spinal cord with the spinal ganglia extends up to the tail. Near the mesonephros the genital ridge is visible, and caudally the metanephric blastemal cap and the dividing ampulla of the metanephric duct. (Fig. 13). Literature descriptions include: $6 \mathrm{~mm}$ (Noden and DeLahunta, 1985), $10 \mathrm{~mm}$ (Schnorr, 1989), 6-11 mm and 0.024-0068 g (Tiedemann and Ooyen, 1978), 7-9 mm, head touches the pericardial swelling, olfactory pits, hands on the limb (Evans and Sack, 1973), neuroblasts in the head ganglia, VIIIth cranial nerve divided and in contact with the otic vesicle (Sainmont, 1906; Windle and Griffin, 1931; Halley, 1955), primordium of Jacobson's organ (WöhrmannRepenning, 1989a), four layers in the retina (Martin, 1890a), lateral fissure of the brain distinct (Martin, 1894b, 1895), $23.1 \mathrm{~mm}$, primordium of the neurocranium is mainly membranous, only in parts cartilaginous (Terry, 1917), auricula, 15-24 mm, differentiation of the pharyngeal arches, formation of the ear hillocks, cervical sinus is closing, face clefts visible, iris pigmented, lens visible, olfactory pit deepened, head touches pericardial swelling, mesonephric ridge outside visible, tail elongated with somites up to the end, hand plate on the limb buds and inside sinusoids of the liver are visible (Günther, 1994), first muscle blastemes (Trnkova-Hergetova and Dylevsky, 1994), stomach spindle-shaped (Knospe, 1996), primordium of the myenterical plexus (Lolova and Itsev, 1983), day 21 (54 somites) the mesonephros is $6.5 \mathrm{~mm}$ long and reaches segment 27, cranial last pronephric remnants are visible (Tiedemann, 1976b), oval primordium of the anal sac, epidermis with 1-2 layers (Schwarz et al., 1983, 1984; Schwarz, 1987).

\section{Stage 14 (Periodus gemmarum membrorum sera):} 21-23 days, 13-30 mm (CRL)

The head of the omphala (gemma sera) is less flexed, nasal processes and maxillary process fuse and the upper lip is formed, eyelids start to form, and the external ear is established around the external auditory meatus by the protuberances around the visceral clefts. The cervical sinus has become obliterated. In the digital plate the outlines of the future digits appear as rays, the midgut is herniated into the extra-embryonic coelom of the umbilical cord. In the region of the cloacal membrane the genital protuberances are formed. Inside the skeleton and muscles differentiate. Vertebra, ribs, stylopdia, cranially also the zeugopodia and at the skull the sphenoid are cartilaginous, the petrosum is still mesenchymal. The optic cup is pigmented, the lens vesicle asymmetrical, the primitive palate, the tongue and the primitive larynx are formed, further differentiation of thymus, thyroid, parathyroids and heart appear, pleural cavities develop around the lungs, which already show lobular bronchi. Stomach with the pyloric part, the omentum and the papilla duodeni are visible, pancreas is lobulated and in the liver the vessels develop. The mesonephros is reduced, the indifferent gonads and the Müllerian duct and the Wolffian duct are formed, urachus and sinus urogenitalis are separated (Fig. 14). Literature descriptions inlcude: $10 \mathrm{~mm}$, primordium of mammary gland, external ear, pigmented optic cup, physiological hernia of the midgut, interdigital furrows (Windle and Griffin, 1931; Evans and Sack, 1973), $10 \mathrm{~mm}, 21$ days, the operculum covers the third branchial arch, differentiation of the pharyngeal pouches and cranial nerves takes place (Halley, 1955), genital ridge elongated and first genital cords are visible (Sainmont, 1906), yolk sac placenta fades till day 24 (Rüsse and Sinowatz, 1991), eye lid, cornea, pigment in the retina and vitreal body develop (Bernis and Wyman, 1980), $9 \mathrm{~mm}$ (Noden and DeLahunta, 1985), digital plate of the hindlimb is distinct, inside tongue formation, gonads, cortex suprarenalis, metanephros and cartilage in the scapula and humerus are developing (Davies, 1973; Günther, 1994), beginning of the branching phase of salivary glands (Knospe and Böhme, 1995), with $13.5 \mathrm{~mm}$ the apical epidermal ridge (AER) is visible (Kato, 1977). 

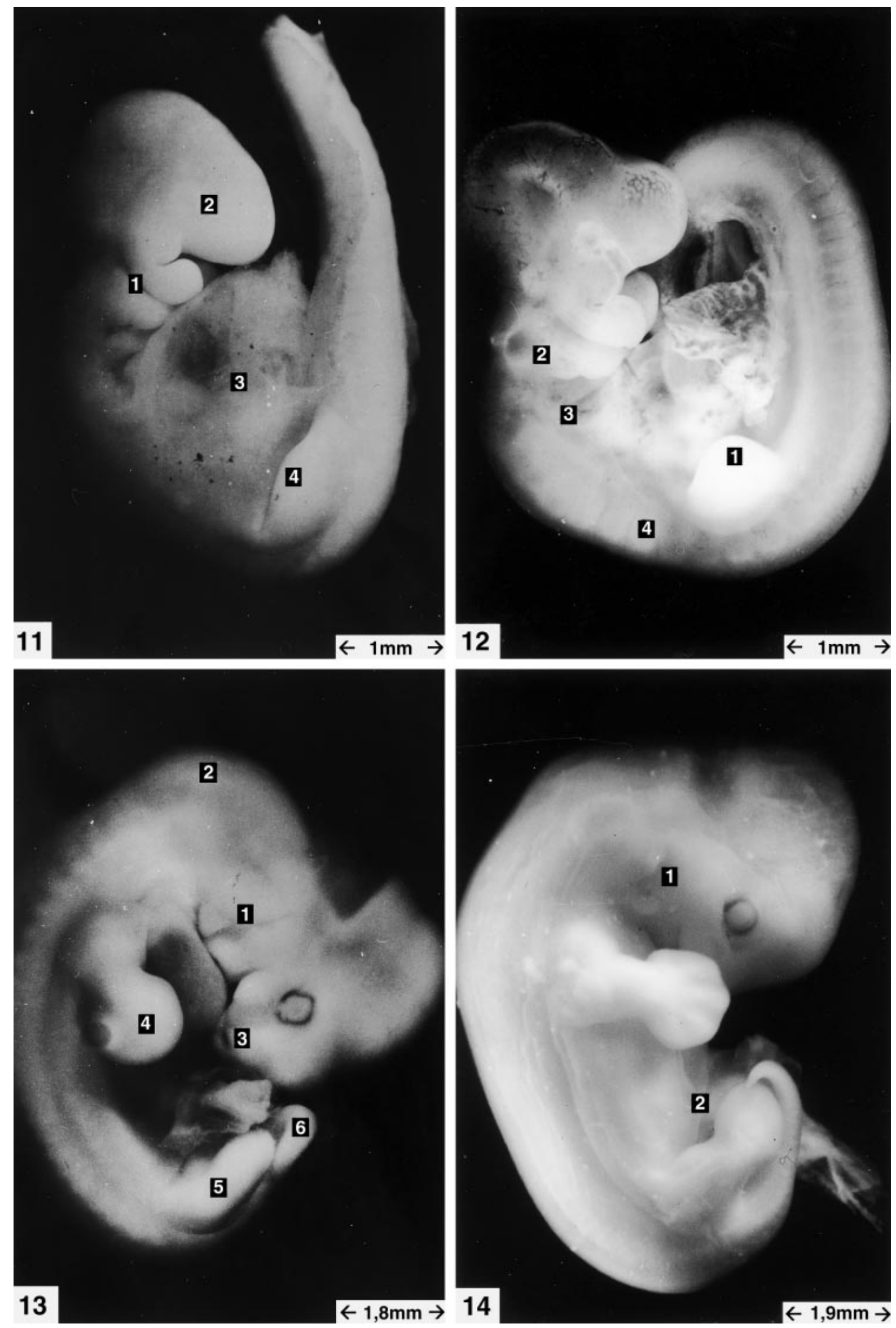
Fig. 11. Stage 11: pharyngula, 18 days. $1=$ pharyngeal arches; $2=$ head with optic cup; $3=$ heart and liver swelling; $4=$ shallow forelimb bud.

Fig. 12. Stage 12: gemmula, 19 days. $1=$ forelimb bud; $2=$ otic vesicle above the second arch; $3=$ cervical sinus; $4=$ somites still visible.

Fig. 13. Stage 13: auricula, 21 days. $1=$ ear tuberculi; $2=$ maximal cervical flexure; $3=$ olfactory pit; $4=$ forelimb; $5=$ hindlimb; $6=$ curled tail

Fig. 14. Stage 14: omphala, 22 days. $1=$ external ear; $2=$ umbilical cord with herniated midgut.

\section{Stage 15 (Periodus labii fissi): 23-25 days, 17-34 mm}

The head of the ceilula with a prominent midbrain is raised, the face furrows fuse, forelimbs have all major segments and pronated digital plates, the fingertips start to separate, the hindlimbs show digital rays, between the limb the mammary buds are visible. In the stylo- and zeugopodium one can already find cartilage; gonads, kidney and adrenals are differentiating. In the primitive spinal cord grey and white matter are separated and surrounded by the primitive meninx. Also spinal nerves and ganglia are differentiating. In the head the mandible and the salivary glands are formed, the palatal processes extend in between the tongue. The brain shows the epiphysis and the primordium of the cerebellum. The epidermal layer becomes stratified, outside the periderm. In the caudal part of the body the phallus is formed by the genital hillocks (Fig. 15). Literature descriptions include: 14-17 mm, eyelid, fore digits separated, external ear is formed (Sainmont, 1906; Evans and Sack, 1973), 14-16 mm, first movements possible (Windle and Griffin, 1931), primordia of gastric glands (Knospe, 1996), corneal stroma, compact lens with first fibres and capillaries, optical and caecal part of the retina are distinct (Bernis and Wyman, 1980), pseudoglandular stage of the lung (Glöckel, 1984), first nail anlagen (Kato, 1977), late embryonal stage, $24-36 \mathrm{~mm}$, the external ear is formed, the naso-lachrymal furrow fused, start of neck development, mamillae dorsolateral, digital plate organized, mesogastrium with the primordium of the spleen, indifferent gonads, eyelid ridges, pseudoglandular lungs, cartilage in the labyrinth, vertebrae and ribs (Günther, 1994), trabecular organized epithelial cells in the thyroid (Velicky and Titlbach, 1986), matrix, mantle and marginal layer are differentiated in the spinal cord (Böhme, 1988), regressive changes from cranial pole of mesonephros proceed caudally (Tiedemann, 1976b), mammary buds with $3.1 \mathrm{~cm}$ (Gisler, 1922), with 16-19 mm toe and finger growth, AER disappears, formation of the primary nail field, first keratohyalin (Kato, 1977), hypophyseal stalk long and narrow (Gilbert, 1934).

\section{Stage 16 (Periodus labii fissi): 25-28 days, 21-40 mm}

During this stage the growing neck of the cervicula stretches the trunk and head. The eyelids are growing, the external ears get marked tips and the face its typical shape by closure of the furrows and formation of cheeks, nose, mouth and chin. Both limbs have separated toes, but still interdigital folds, the forelimbs have pronated hands. The umbilical hernia is reduced, the mammillary buds are more ventrally shifted. The body cavities are organized by septa pleuropericardiaca, plicae mesonephridica and the septum transversum. The septum urorectale reaches the cloacal membrane, which is breaking. The organs further differentiate. Haematopoiesis in the liver, pseudoglandular stage of the lung, the hypophysis becomes lobed, formation of gastric glands and intestinal villi, pancreas differentiation, formation of primitive glomerula in the kidney, mesonephros in regression, different stage of the gonads, differentiation of muscles, nerves, formation of connective tissue, cartilage and joints. Carpals, toes and ribs are still cartilaginous, the zeugopodium starts perichondral ossification. Inside the head, orbital muscles, eyes, palate and teeth anlagen are formed. The tongue touches the nasopharynx and shows outside papillae and inside the blastemes of tongue muscles. Bone formation in maxillary and mandibular anlagen. Formation of laryngeal cartilage, turbinate and nasal septum. Temporal bone is cartilaginous, parietal mesenchymal. Differentiation of the internal ear, cavum tympani, brain and meninx. In the skin blastemes of muscles and tactile hairs germs in bulbus stage appear. Under the skin a big clavicular sac is visible (Fig. 16). Literature descriptions include: 15$20 \mathrm{~mm}$ (Sainmont, 1906; Ackermann, 1967), 19.5-22 mm (Windle and Griffin, 1931; Evans and Sack, 1973), 19-29 mm and $0.28-1.00 \mathrm{~g}$ (Tiedemann and Ooyen, 1978), haematopoiesis in the yolk sac (Ooyen, 1977), secondary lens fibres (Bernis and Wyman, 1980), $16 \mathrm{~mm}$ (Noden and DeLahunta, 1985), $19 \mathrm{~mm}$ (Schnorr, 1989), primordium of the plexus chorioidei latt. (Künzel and Böhme, 1981), tactile hair buds, external ear triangular, somites are no longer visible, forelimb turned, digits separated (Günther, 1994), corpus callosum weak (Martin, 1894a, b, 1895), 21-25 mm, cartilaginous tendency is evident in the distal phalanx and keratinization of the nail field has started (Kato, 1977), adrenals produce corticoids and pituitary adrenocorticotropin (Bukulya et al., 1976), between the 25th and 38th day differentiation and activity of the yolk sac endodermal epithelium starts (Tiedemann, 1976a).

\section{Stage 17 (Periodus fetalis initialis): $28-32$ days, $25-50 \mathbf{~ m m}$}

The early fetus grows rapidly and most parts have reached their definitive positions. The forehead is prominent, eyes closed by the rapidly growing eyelids, short, triangular ear, tactile hair buds in the lips, typical mouth with mental cushion, nose with keratinization at the planum, short neck, trunk relatively slim, back with slight lordosis, heart and liver region are less protuberant and the hernia of the midgut is withdrawn. The mammary buds are paramedial, free tail, all three major segments of the limbs are clearly demarcated, now also the foot is pronated, toes separated with pads and claws, undifferentiated genitals (Fig. 17). Inside, cartilaginous phalanges, osseous stylo-, zeugopodia, metacarpals, metatarsals, hip and shoulder joint in development. Inside the head nasale, parietale, frontale, palatinum, incisivum, sphenoidale, maxillare and the mandible are in desmal ossification, occipitale and temporale are cartilaginous. Also in the external ear and the larynx cartilage are formed. In the nasal cavity, conches, septum and vomeronasal organ are formed. The palate contains remnants of the craniopharyngeal duct and exhibits an epithelial joint and the primordia of the palatal rugae. In the mouth salivary glands and teeth are developing. In the orbita the conjunctiva, muscle primordia, fasciae and the lachrymal gland are formed. Differentiation of the inner ear, tympanum, brain, spinal cord, hypophysis and thymus are in progress, also the heart and the trachea. First enchondral 
ossifications appear in the ventral centra of the thoracic region, the neural arches form perichondral collars around the base of the cartilaginous arch, intervertebral discs with remnants of the notochord are seen. The ribs start ossification and between them the intercostal muscles are formed, sternebrae start to fuson of the sternal bars. The lung is in the canalicular stage and the differentiation of the bronchi is in progress. The luminal diameter of the oesophagus is narrowed by the developing layers. The stomach has all its layers, like the intestine, which begin with the formation of the intestinal villi. Lobulation and haematopoiesis take place in the liver, differentiation of the liver venes, pancreatic tubules and islets, spleen still compact, adrenal cortex and medulla are separated. Behind the regressing mesonephros the kidneys with primitive glomerula and branched ducts are distinct. Testes and ovaries are already separated in cortex and medulla with the rete blasteme and cords. Formation of uterus and bladder. Literature descriptions include: $20-30 \mathrm{~mm}$, toes separated, tongue visible, external acoustic meatus covered, hair follicles in development, eyelids closed, formation of the claws, differentiation of testes and ovary (Sainmont, 1906; Windle and Griffin, 1931; Evans and Sack, 1973), $26 \mathrm{~mm}$, lymphocytes are scattered in the developing lymph nodes (Ackermann, 1967), $31 \mathrm{~mm}$ (Schnorr, 1989), eyelids have fused with hair follicles in their outer surface, third eyelid is present, sclera with primordia of the extrinsic muscles and the anterior chamber are formed, corneal differentiation, retinal pigment (Bernis and Wyman, 1980), plexus choreoidei III and IV distinct (Künzel and Böhme, 1981), Nuda with 36-60 mm, typical head, triangular ear, lid formation, dental lamina with tooth buds, diaphragm in development, first hair germs in the skin of the backside, nipples at the abdomen, claws at the forelimbs, digits separated, inside ossification centres in the maxilla, mandible, scapula, humerus and femur (Günther, 1994), septum dorsale of the spinal cord (Böhme, 1988), with $4.6 \mathrm{~cm}, 28$ days ossification of the scapula, clavicle, stylo- and zeugopodial regions (Schaeffer, 1932), 26-29 mm keratinization of the claws (Kato, 1977).

\section{Stage 18 (Periodus fetalis initialis): 32-38 days, 35-60 mm}

The fetus grows rapidly, the head remains relatively large, but the trunk region is slimmer, the external ear is more obvious, the umbilical cord is reduced in size, the limbs are in the typical fetal position, elbow and hock free and flexed, with the preaxial borders directed cranially, the digits of both fore- and hindfeet are clearly defined with keratinization of the claws. The skin is smooth, without hairs (nuda), the nipples are more ventral and the external genitals are differentiating (Fig. 18). The perichondral ossification begins at the midshaft of zeugopodial and metapodial bones, proximal in the ribs, the scapula is still cartilaginous but with a desmal ossified spina. The neural arch of some vertebrae are already closed, the intervertebral disks develop. In the eye one can find vitreal formation, chamber differentiation, formation of iris, tarsal glands and lachrymal ducts. The nasal conches are cartilaginous, also development of the dentition, lobulation of the salivary glands and formation of the tongue papillae are in progress. The petrosal becomes cartilaginous, the cortex cerebri is in differentiation, also the hypophysis and thyroid. The trachea already has cartilage. In the thoracic cavity we find further development of the sympathic trunk, myocardium,
Fig. 15. Stage 15: ceilula, 25 days.

Fig. 16. Stage 16: cervicula, 28 days.

Fig. 17. Stage 17: early fetus, 32 days.

Fig. 18. Stage 18: nuda, about 36 days.

vessels, bronchi and in the abdominal cavity gland buds in the stomach, elongation of the omentum, intestinal crypts and villi, venosal duct, ligaments of the liver, adrenal and kidney. The Müllerian duct is reduced in the male fetus. The gonads already show the rete, tunica albuginea, cords and ductuli efferentes. The bladder develops the muscle layer. Literature descriptions include: $43-45 \mathrm{~mm}$ and $4.2 \mathrm{~g}$ (Tiedemann and Ooyen, 1978), 36-38 mm, closure of the eyelids and the palatal folds (Windle and Griffin, 1931; Evans and Sack, 1973), 35 mm, first lymphoblasts in the thymus (Ackermann, 1967), plexus chorioidei differentiated (Künzel and Böhme, 1981), corpus callosum is curved, the sylvian fissure in formation (Martin, 1894a, b, 1895), the lumen of the developing spinal cord is gradually reduced (Böhme, 1988), formation of the retinal reticulum (Halasz and Stone, 1984), the follicular cells of the thyroid become progressively polarized (Velicky and Titlbach, 1986), first taste buds (Tichy, 1993), palatal closure, thyroid follicles, hair germs in the whole integument, rotation of the hindlimb and claw formation, undifferentiated phallus, first pancreas islets (Günther, 1994), 49.7-51.1 mm (29 days), parietale, frontale, squamosum, jugale, maxillare, nasale, dentale in ossification (Drews, 1933; Timm, 1987a, b, c, d), end of clavicle formation (Rojas and Montenegro, 1995), 31-32 days, 63-65 mm, ossification begins in metacarpal and metatarsal II-V, the distal phalanges of the forelimb and ilium (Schaeffer, 1932), 33-46 mm formation of corona unguis, keratogenous zone and stratum corneum unguis and appearance of vallum unguis and sulcus unguis which accompany the formation of the corona (Kato, 1977), plexus myentericus between the muscle layer of the stomach end intestine (Lolova and Itsev, 1983), $38 \mathrm{~mm}$, ovary distinct, but border of the medulla broken by many epithelial cords of the cortex (Sainmont, 1906), indifferent stage of the external genital organs (Künzel, 1976), lobular stage of the mammary gland (Teske, 1986), mammary bud with beginning of nipple formation, hair pegs and sweat gland buds in the integument (Gisler, 1922), 55 mm, ectodermal anal glands (Krölling, 1927).

\section{Stage 19 (Periodus fetalis initialis): $38-44$ days, $50-80 \mathrm{~mm}$}

Beside rapid growth of all body parts of the nuda, the differentiation of the skin and its derivates is remarkable. The skin thickens and becomes wrinkled, the axillar and stifle fold are marked, the external ears are elongated, the connected ends of the eyelids are presented merely by a transverse furrow, the first rudiments of the vibrissal hair appear, other hair follicles are in the bulbous-peg stage and the claws show claw folds and keratinization. In the caudal body part the elongated tail and the phallus are prominent (Fig. 19). The lung is in the stage of terminal sacculi. The saccus clavicularis of the lymphatic system is prominent in the upper chest. In the middle ear, rudiments of the inner muscle are formed. Petrosum, occipitale, temporale, chonchae and septum nasi are still cartilaginous. Organum vomeronasale is in differentiation, the hypophysis is lobed, thymus is separated into neck and thoracic parts, parathyroids are shifted near the thyroid gland, the first two neck joints are distinct, the neural arch of lumbal 

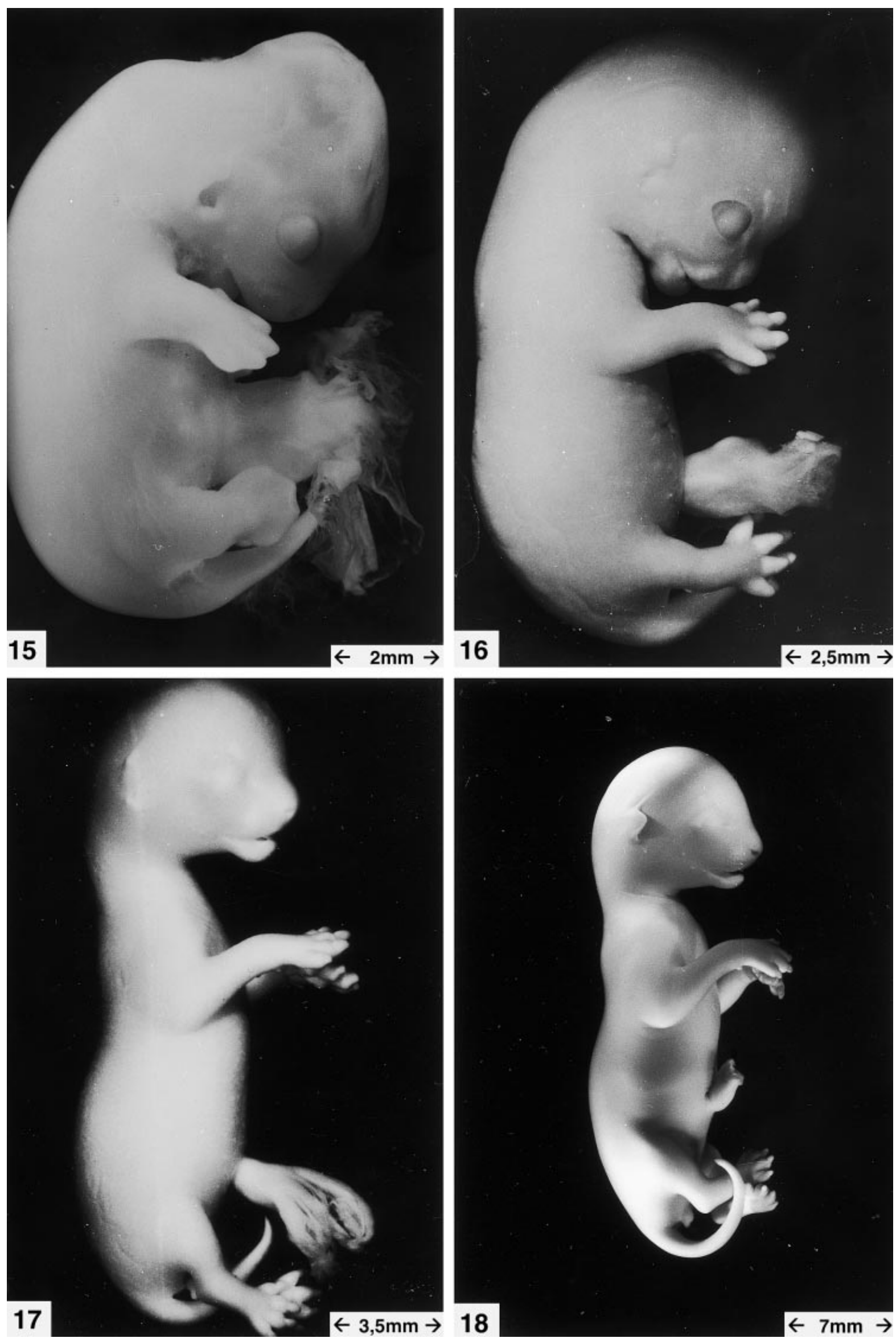
vertebrae are closed, in the liver haematopoiesis is occurring, the intestinal lumen is nearly obstructed by the growing villi, first goblet cells, differentiation of the plica urogenitalis, kidney with medulla and cortex and differentiating tubuli. Literature descriptions iclude: 45-70 mm (Schnorr, 1989), $70 \mathrm{~mm}$ and $14.0 \mathrm{~g}$ (Tiedemann and Ooyen, 1978), internodal swellings of the uterus are less prominent (Rüsse and Sinowatz, 1991), type II vestibular cells are innervated (Favre and Sans, 1979), 39 days, 49-73 (61) $\mathrm{mm}$, vomeronasal organ in differentiation (Wöhrmann-Repenning, 1989b), ciliary processes can be identified, the choriocapillaris, large choriodal vessel and vessels in the iris and corneo-scleral junction develop, first bundles of orbicularis oculi muscle in the lids and the cartilage of the third eyelid are identified, formation of retinal layers (Büssow, 1974; Bernis and Wyman, 1980), separation phase of the salivary glands (Knospe and Böhme, 1995), development of the vallate papillae (Tichy, 1993), 50-80 mm, the thymus is filled with medium-sized and small lymphocytes (Huntingdon and McClure, 1910, 1920; Windle and Griffin, 1931; Ackermann, 1967), number and size of intrafollicular lumina increase in the thyroid (Velicky and Titlbach, 1986), the lumen of the spinal cord is reduced to the final central canal (Böhme, 1988), first myelinization of the nerves (Chun and Shatz, 1989), canalicular stage of the lung (Glöckel, 1984), first glands and glandular pits in the stomach (Knospe, 1996), formation of the colon transversum (Krüger, 1929), haematopoiesis in the spleen (Ooyen, 1977; Canfield and Johnson, 1984), 50-65 $\mathrm{mm}$, ovarian differentiation (Sainmont, 1906), 50-90 mm, ovary with cords and oogonia, mesonephros reduced (Tiedemann, 1976b), Nuda vibrissa, eyelids closed, claws in differentiation, breakthrough of the vibrissae, physiological hernia of the midgut reduced, canalicular lung, genitals differentiated (Günther, 1994), hair development is well established, epidermis with five layers, hair follicles and sebaceous gland buds in the upper third (Baker, 1974), $55 \mathrm{~mm}$ and $4.8 \mathrm{~g}$, first visible vibrissae in the head region (Evans and Sack, 1973), mammary glands with nipples in the bulbous stage, hair follicles in bulbous-peg stage (Gisler, 1922), hair germs in the dorsal skin, circumoral sweat gland germs (Backmund, 1904), 65-75 mm, differentiation of the paranal sinus, first hairs in the skin (Schwarz et al., 1983, 1984; Schwarz, 1987), dimorphism of the external genitals (Künzel, 1976), $7.1 \mathrm{~cm}, 35$ days, ossification of the distal phalanges of the hindlimb and with $8.4-8.7 \mathrm{~cm}$, 38-43 days, ossification of McI, Ph I of the forelimb and the body of the ischium (Schaeffer, 1932).

\section{Stage 20 (Periodus fetalis definitiva): 44-48 days, 59-94 mm}

Beside further enlargement the hairs of the integumentum commune are now free. They give the embryo a smooth and velvety appearance. The tongue is exposed through its elongation (Fig. 20). Literature descriptions include: $70-80 \mathrm{~mm}$ (Ackermann, 1967), 45 days, $7 \mathrm{~cm}$, testicle differentiation (Sainmont, 1906), 81-100 mm and 21.9-34.5 g, fine body hair, pigmented nose, claws (Evans and Sack, 1973; Tiedemann and Ooyen, 1978) $90 \mathrm{~mm}$ (Windle and Griffin, 1931), last erythroblasts in the blood (Rüsse and Sinowatz, 1991), end of the yolk sac period of haematopoiesis and the begin of it in the liver and the bone marrow (Ooyen, 1977), Jacobson's organ developed, nasopalatal duct still closed (Wöhrmann-Repenning, 1989b), with 48 days Descemet's membrane is distinct, the ciliary processes are increasing in number (Bernis and Wyman, 1980), primordium of the anal sac (Schwarz, 1987), $85 \mathrm{~mm}$ (Schnorr, 1989), cell differentiation in the hypophysis (Brahms, 1932), tactile hairs on upper lips and eyebrow, nipples ventral in their definitive position, limbs turned and claw keratinized (Günther, 1994), primary hairs free, secondary hairs in differentiation, group orientation of hairs distinct (Baker, 1974), labial gland in development (Künzel and Knospe, 1986), sulcus and fissure rhinalis, lobus piriformis and fissura sylvii are formed (Martin, 1895), $9.3 \mathrm{~cm}$, mammary gland with nipples, hairs of the skin, sweat gland differentiation (Gisler, 1922), at the cranium in 94.1-95.5 mm (about 46 days), all desmocranial bones are well formed, beginning of the formation of the tentorium, basal beside cartilaginous parts also secondary bone at the basioccipitale, capsula otica and sphenoid, endotympanicum and Reichert's cartilage are still cartilaginous, while Meckel's cartilage and middle ear ossicles start ossification. The orbitotemporal region is elongated (Timm, 1987a, b, c, d).

\section{Stage 21 (Periodus fetalis definitiva): 48-60 days, 65-125 mm}

Possible pigmentation now becomes distinct and the lanugo is wrinkled by rapid skin growth (Fig. 21). Literature descriptions include: $98 \mathrm{~mm}$ hair, pigmentation and claws distinct (Evans and Sack, 1973), 70-120 mm lanugo (Sainmont, 1906), $103 \mathrm{~mm}$ (Windle and Griffin, 1931), 108-125 mm (Schnorr, 1989), corpus callosum is elongated and the sulcus coronalis, suprasylvius lateralis, sylvii, cruciatus, splenialis are formed (Martin, 1894a, b, 1895), first neurotransmitters in the brain (Chun and Shatz, 1989), in the retina all layers are formed (Ramoa et al., 1988), and start differentiation (Rapaport and Stone, 1983), the gland of the third eyelid starts its development, also the tarsal glands, first signs of iris muscles, the irido-corneal region is fully developed, blood vessels at the cornea-scleral junction are well outlined (Bernis and Wyman, 1980), first astrocyts in the optical nerve (Ling and Stone, 1988), vestibular nerve in the promyelin stage (Romand et al., 1976; Berthold et al., 1983), stage of terminal sacs of the lung (Glöckel, 1984), gustatory glands (Tichy, 1993), the prenatal differentiation of the salivary glands starts (Knospe and Böhme, 1995), first glandular branches in the stomach, the penis is differentiated, but the corpus cavernosum is still weaker as the corpus spongiosum, the prepuce is still connected (Martin, 1890c), 11.5-14.5 cm, 49-55 days, ossification of the humerus epiphyses, os pubis, os tarsi tibiale, os tarsi fibulare and toes (Schaeffer, 1932), articular cartilage becomes smooth (Horky, 1993, 1994), muscle blastemes with distinct fibres (Hoh and Hughes, 1989), lanugo, 90-120 mm, hair, wrinkles and pigment pattern of the skin is distinct (Günther, 1994), first sebaceous glands in the mentum (Backmund, 1904), proliferation of the labial gland (Künzel and Knospe, 1986), primary branches of the mammary gland, hairs free, first sebaceous glands (Gisler, 1922; Turner and DeMoss, 1934), with $90 \mathrm{~mm}$ conus formation and with 115-125 mm cavitation of the anal sac, first follicles and glands in the skin (Schwarz, 1987; Schwarz, 1987), $116 \mathrm{~mm}$, division of stratum corneum

Fig. 19. Stage 19: nuda, 38 days

Fig. 20. Stage 20: late fetus, about 46 days.

Fig. 21. Stage 21: lanugo, 60 days

Fig. 22. Stage 22: partus, 63 days. 

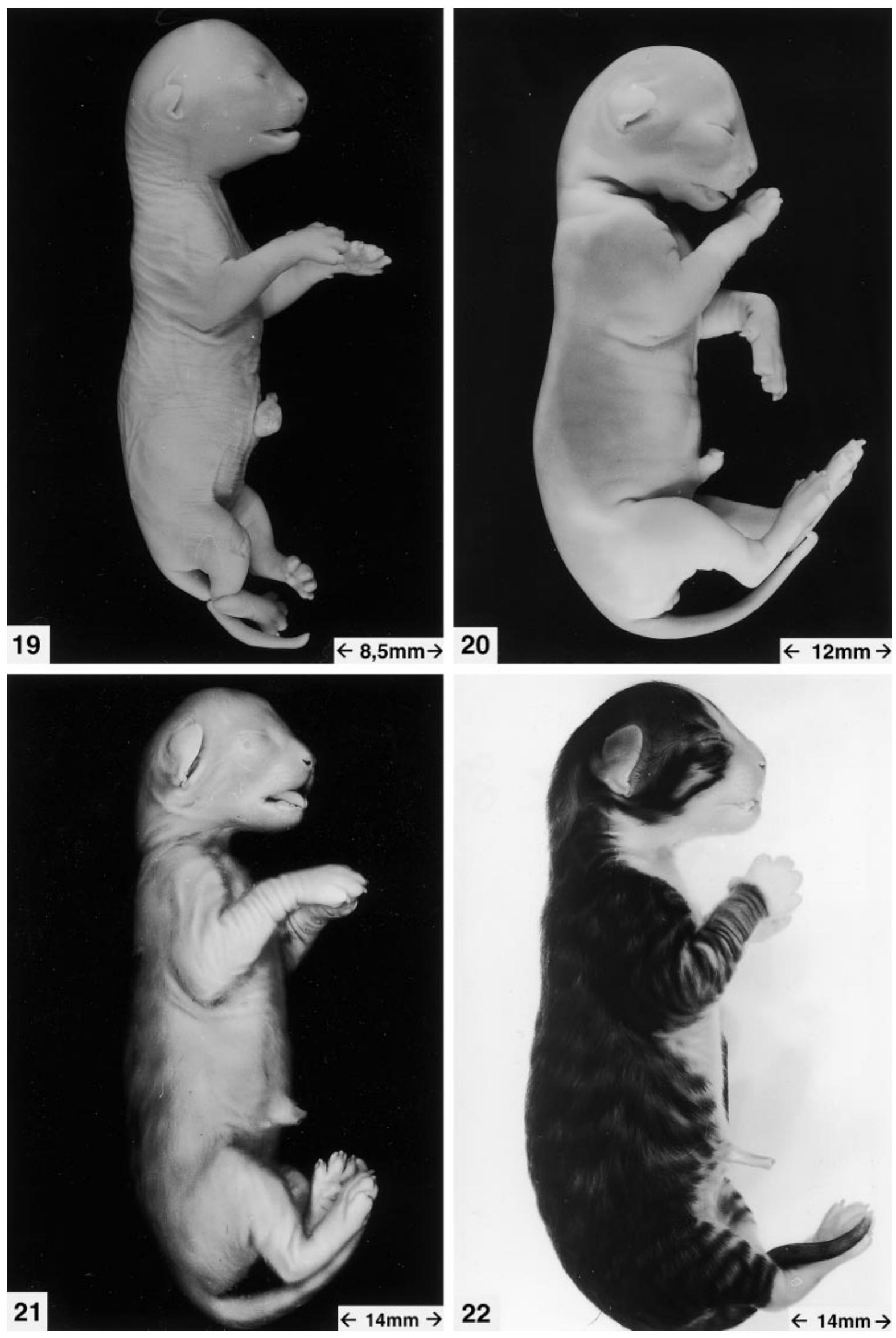
unguis into two layers and completion of stratum tectorium, paries unguis is formed, capillaries have penetrated into sulcus matricis (Kato, 1977).

\section{Stage 22 (Periodus fetalis definitiva): 58-66 days, 90-186 mm}

This is the stage of the mature fetus (Partus) just before or during birth. (Fig. 22) Literature descriptions include: 120-125 mm (Sainmont, 1906), 83.5-131 g (Tiedemann and Ooyen, 1978), haematocrit 47 (Ooyen, 1977), neuroepithelial bodies in the mature lung (Vanlommel and Lauweryns, 1993), plexus myentericus differentiated (Lolova, 1983), $140 \mathrm{~mm}$ (Schnorr, 1989), alveolar stage of the lung (Glöckel, 1984), mature, thick hair coat, first alveolar ducts (Günther, 1994), bronchial glands differentiated (Höfliger and Stünzi, 1975), 60-63 birth, carotid body differentiated (Clarke and Daly, 1984, 1985), first retinal vascularization (Halasz and Stone, 1984), epiglottal taste buds in differentiation (Stedman et al., 1983), gastric lipase detectable (Knospe and Plendl, 1997), before birth the lip gland increases in size, after birth it is reduced (Claassen, 1930; Künzel and Knospe, 1986), formation of the colon ascendens (Krüger, 1929), mammary gland with three to five primary buds, nipples with reduced hairs (Gisler, 1922).

\section{Discussion}

Any embryological study of a certain species needs a chronological grouping of the research material to allow for comparison of different investigations, hence staging (Erdl, 1845), or standardization (Keibel, 1900) has been used for a long time. It is available for a number of different species, as well as for interspecies comparisons, and has been used since the 19th century to allow general statements to be made on developmental events (His, 1868; Oppel, 1891). As a result, it has been stated that mammals share similar developmental phases, but no clear assignment to time, course or order of events has been established.

Just as in human development, a sequence of prenatal development of the dog was developed (Phemister, 1974), describing three periods: (1) the period of the ovum (blastocyst), (2) the period of the embryo, and (3) the period of the fetus. However, this division is too simple for a detailed comparison. Günther (1994) describes 10 interspecies stages, and finally the Nomina Embryologica Veterinaria (Frewein et al., 1994) divides the prenatal development, more precisely, into 15 periods, which are also used in this study to characterize the development of the cat, namely:

(1) Conceptio/Blastogenesis,

(2) Morulatio,

(3) Blastulatio,

(4) Gastrulatio,

(5) Neurulatio (Periodus sulci neuralis initialis),

(6) Periodus mesodermalis et mesenchymalis,

(7) Periodus sulci neuralis maturi et somitorum immaturorum,

(8) Periodus tubi neuralis,

(9) Periodus pharyngealis initialis,

(10) Periodus pharyngealis ultima,

(11) Periodus gemma membrorum initialis,

(12) Periodus gemmarum membrorum sera,

(13) Periodus labii fissi,

(14) Periodus fetalis initialis, and

(15) Periodus fetalis definitiva.
To designate the embryo in different periods the terms given by NEV $(0,2-6,22)$ and by Günther $(11,13,16,18,21)$ were used or new terms are proposed. These periods are useful for interspecies comparison, but for most experimental studies in cats these 15 periods are not accurate enough, especially in early embryos. Therefore additional stages are introduced, altogether 22 stages in the mentioned 15 periods to make interand intraspecies comparative studies possible.

For a clear and easy staging, it was necessary to rely on visible, external, morphological, but not on fine- or ultrastructural, features for the description of developmental stages. Common criteria are length, weight, developmental time, for early embryos also the number of somites or pharyngeal arches, for older embryos and for fetuses the development of the extremities and skin derivates (Habermehl, 1975). It is evident, that there are more embryonic than fetal stages, because of the existence of more noticeable changes in a shorter time span. External changes in the fetal stages are more quantitative, and not all histological changes can be used for a meaningful staging. This is also true for some very detailed references on the organo- or histogenesis, for instance in the development of the skull by Timm (1987), of which only important facts are mentioned. Some of the older literature could barely be used (Martin, 1890a, b, c, 1891a, b, 1894a, b, 1895) or was not used at all (Latimer, 1931, 1933, 1934a, b, 1935, 1938, 1939a, b, 1940, 1941, 1942, 1943, 1944a, b, 1948) because of unusable results or lack of time specification. Time specification is the biggest problem in comparative embryology.

Unless precise data of coitus or developmental time are available, it is necessary to use the size of an embryo in any attempt to estimate its age. For this purpose the crown-rump length (CRL) is usually employed, which is the measurement from the vertex of the skull along the back to the breech at the base of the tail. In early somite embryos the total length is measured. Discrepancy of the results may be caused by different methods or faulty measurements, but again, the present study confirms results found in the literature (Allen and MacDowell, 1940; Grüneberg, 1954; Otis and Brent, 1954; Nishimura et al., 1968; Yamamura, 1969; von Kobyletzki and Gellen, 1970; Gottschewski and Zimmermann, 1973; Günther, 1994; Sivachelvan et al., 1996), that length and weight of individual embryos, even within a litter, vary considerably, so that there is no absolutely accurate method of estimating the age of an embryo from its length or weight. Even the gestation period varies in cats (Root et al., 1995). Preparation and fixation produce additional differences, as sonographic studies in living and fixed embryos proved (Drumm and O'Rahilly, 1977; Dickey and Gasser, 1993). Therefore these data could only be used together with typical developmental features, which in reverse are solely insufficient for comparison (see Zietzschmann-Krölling, 1955). For this reason all studies (Evans and Sack, 1973; Habermehl, 1975; Noden and DeLahunta, 1985; Schnorr, 1989), which were limited to only one feature are restricted with their results, even time, length and weight are somehow connected. Therefore a developmental formula has no practical use (Eaton, 1952; Bünger, 1972; Nelson and Cooper, 1975).

Even working with embryos that are well dated, we must consider that starting points and their definition can be different (Fleischmann, 1889; Hill and Tribe, 1924; Latimer, 1931; Dawson and Kosters, 1944; Enders, 1970; Denker et al., 1978; McLaren, 1978) and may cause differences, especially in 
early embryos. Here the developmental time is given as post coitum, which always took place only once in a 1-h observed period. The first fertilized eggs cells were found 20-28 h later, which corresponds with the new report by Wildt et al. (1998). After that the embryo divides every $12 \mathrm{~h}$, reaching the uterus in the blastocyst stage within about $148 \mathrm{~h}$. The zonalysis starts at 12 days, the implantation at 13-14 days. In vitro experiments with cats result in accelerated development (Pope et al., 1993; Kanda et al., 1995). The division could be early asynchronous, especially after fixation, but such embryos should not be described as a special stage.

\section{References}

Ackermann, G. A., 1967: Development relationship between the appearance of lymphocytes and lymphopoietic activity in the thymus and lymph nodes of the fetal cat. Anat. Rec. 157, 387-400.

Allen, E., and E. C. MacDowell, 1940: Variation in mouse embryos of 8 days gestation. Anat. Rec. 77, 165-173.

Amoroso, E. C., 1952: Placentation. In: Marshall's Physiology of Reproduction (A. S. Parke, ed.). Vol. II, 3rd edn. London: Longmanns, Green and Co.

Backmund, K., 1904: Die Entwicklung der Haare und Schweißdrüsen der Katze. Vet. Med. Diss. Zürich

Baker, K. P., 1974: Hair growth and replacement in the cat. Br. Vet. J. 130, 327-335.

Bernis, W. O., and M. Wyman, 1980: Prenatal development of the eye of the cat (Felis domestica). Arq. Esc. Vet. Uni. Minas-Gerais 32, 283-304.

Berthold, C. H., I. Nilsson, and M. Rydmark, 1983: Axon diameter and myelin sheath thickness in nerve fibres of the ventral spinal root of the seventh lumbar nerve of the adult and developing cat. J. Anat. 136, 483-508.

Böhme, G., 1988: Formation of the central canal and dorsal glial septum in the spinal cord of the domestic cat. J. Anat. 159, 37-47.

Brahms, S., 1932: The development of the hypophysis of the cat (Felis domestica). Am. J. Anat. 50, 251-282.

Bremer, M. P., 1992: Vergleichende Untersuchung zur frühen Entwicklung der Speiseröhre bei Ente, Katze und Schaf. Vet. Med. Diss. Berlin.

Bünger, I., 1972: Beitrag zur Altersbestimmung von Feten des deutschen schwarzbunten Rindes insbesondere auf Grund von Längenmessungen. Vet. Med. Diss. Hannover.

Büssow, H., 1974: Zur Histogenese und Cytogenese des Tapetum lucidum cellulosum der Katze. Eine licht- und elektronenmikroskpische Untersuchung. Anat. Embryol 146, 141-156.

Bukulya, B., K. Szalay, E. Stark, and J. Marton, 1976: Immunocytochemical study of the hypophysis of cat embryos. Anat. Histol. Embryol. 5, 99.

Canfield, P. J., and R. S. Johnson, 1984: Morphological aspects of prenatal haematopoietic development in the cat. Zbl. Vet. Med. C 13, 197-221.

Chun, J. J., and C. J. Shatz, 1989: The earliest-generated neuron of the cat cerebral cortex: characterization by MAP2 and neurotransmitter immunohistochemstry during fetal life. J. Neurosci. 9, 1648-1667.

Claassen, P., 1930: Die Entwicklung der Zirkumoraldrüse der Katze. Zschr. Mikrosk.-Anat. Forsch. 21, 497-530.

Clarke, J. A., and M. D. Daly, 1984: Carotid body in the fetal cat and newborn kitten. Acta Anat. 120, 84.

Clarke, J. A., and M. D. Daly, 1985: The Volume of the carotid body and periadventitial type I and type II cells in the carotid bifurcation region of the fetal cat and kitten. Anat. Embryol. Berl. 173, 117-127.

Coulter, C. B., 1909: The early development of the aortic arches of the cat, with special reference to the presence of the fifth arch. Anat. Rec. 3, 578-592.
Courrier, R., and G. Gros, 1935: Contribution à l'endocrinologie de la grossesse chez la chatte. C. R. Soc. Biol. 120, 5-7.

Davies, S., 1973: The development of the adrenal gland of the cat. J. Mikr. Sci. 80, 81-98.

Dawson, A. B., and B. A. Kosters, 1944: Preimplantation changes in the uterine mucosa of the cat. Am. J. Anat. 75, 1-37.

Denker, H. W., L. A. Eng, U. Mootz, and C. E. Hamner, 1978: Studies on the early development and implantation in the cat. I. Cleavage and blastocyst formation: Differentiation of the trophoblast and embryonic knot cells. Anat. Anz. 144, 457-468.

Dickey, R. P., and R. F. Gasser, 1993: Computer-analysis of the human embryo growth curve differences between puplished ultrasound findings on living embryos in-utero and data on fixed specimens. Anat. Rec. 237, 400-407.

Drews, M., 1933: Über Ossifikationsvorgänge am Katzen- und Hundeschädel. Gegenbaurs morph. Jb. 73, 185-237.

Drumm, J. E., and R. O'Rahilly, 1977: The assessment of prenatal age from the crown-rump length determined ultrasonically. Am. J. Anat. 148, 555-560.

Eaton, O. N., 1952: Weight and length measurements of fetuses of Karakul sheep and goats. Growth 16, 175-187.

Enders, E. S. E., 1970: Fertilization, cleavage, and implantation. In Reproduction and Breeding techniques for Laboratory Animals (M. S. Hafez, ed.). Philadelphia: Lea and Febiger, pp. 137-156.

Erdl, M. P., 1845: Die Entwicklung des Menschen und des Hühnchens im Eie. 1. Bd. Entwicklung der Leibesform. Leipzig: Voss.

Evans, H. E., and W. O. Sack, 1973: Prenatal development of domestic and laboratory animals. Zbl. Vet. Med. C 2, 11-45.

Favre, D., and A. Sans, 1979: Embryonic and postnatal development of afferent innervation in cat vestibular receptors. Acta Otolaryngol Stockh. 87 (1-2), 97-107.

Fleischmann, A., 1889: Embryologische Untersuchungen. 1. Heft: Untersuchungen über einheimische Raubtiere. Wiesbaden: Kreidel.

Fraser, E. A., 1920: The pronephros and early development of the mesonephros in the cat. J. Anat. 54, 287-304.

Frewein, J., R. E. Habel, and W. O. Sack, 1994: Nomina Anatomica Veterinaria, 4th edn; Nomina Histologica, 2nd edn; Nomina Embryologica Veterinaria. Zürich, Ithaca, New York: WAVA.

Gilbert, M. S., 1934: The development of the hypophysis: factors influencing the formation of the pars neuralis in the cat. Am. J. Anat. 54, 287-313.

Gilbert, W. W., 1947: The origin and development of the extrinsic ocular muscles in the domestic cat. J. Morph. 81, 151-193.

Gisler, E., 1922: Die Entstehung der Milchdrüse bei der Katze. Vet. Med. Diss. Zürich.

Glöckel, J., 1984: Zur fetalen Lungenentwicklung der Katze. Vet. Med. Diss. Berlin.

Gottschewski, G. H. M., and W. Zimmermann, 1973: Die Embryonalentwicklung des Hauskaninchens. Hannover: Schaper.

Greulich, G., 1934: Artificially induced ovulation in the cat (Felis domestica). Anat. Rec. 58, 217-224.

Grüneberg, H., 1954: Variation within inbred strains of mice. Nature 173, 674-676.

Günther, J., 1994: Vergleichende Untersuchung zum Problem der Entwicklungsstadien bei Huhn, Maus, Katze, Schaf und Mensch. Vet. Med. Diss. Berlin.

Habermehl, K. H., 1975: Die Altersbestimmung bei Haustieren und Labortieren. 2. Aufl.Berlin, Hamburg: P. Parey.

Halasz, P., and J. Stone, 1984: Development of retinal vasculature in the cat. J. Anat. 139, 187.

Halley, 1955: The placodal relations of the neural crest in the domestic cat. J. Anat. 89, 133-152.

Hill, J. P., and M. Tribe, 1924: The early embryology of the cat (Felis domestica). Q. J. Micr. Sci. 68, 513-602.

His, W., 1868: Die erste Entwicklung des Hühnchens im Ei. Leipzig: Vogel. 
Höfliger, H., and H. Stünzi, 1975: Beitrag zur Entwicklung und zum Bau der Bronchialdrüsen der Katze. Schweiz. Arch. Tierheilk. 117, 475-484.

Hoh, J. F. Y., and S. Hughes, 1989: Immunocytochemical analysis of the perinatal development of cat masseter muscle using anti-myosin antibodies. J. Muscle Res. Cell. Motil. 10, 312-325.

Horky, D., 1993: The ultrastructure of articular-cartilage in the prenatal cat. Acta Vet. (Brno) 62, 115-120.

Horky, D., 1994: Feline articular-cartilage in the prenatal and early postnatal periods a scanning electron-microscopic study. Acta Vet. (Brno) 63, 33-39.

Huntingdon, G. S., and C. F. W. McClure, 1910: The anatomy and development of the jugular lymph sacs in the domestic cat (Felis domestica). Am. J. Anat. 10, 178-309.

Huntingdon, G. S., and C. F. W. McClure, 1920: The development of the veins in the domestic cat. Anat. Rec. 20, 1-30.

Kanda, M., H. Oikawa, H. Nakao, and T. Tsutsui, 1995: Early embryonic development in vitro and embryo transfer in the cat. J. Vet. Med. Sci. 57, 641-646.

Kato, T., 1977: A study on the development of the cat claw. Hiroshima J. Med. Sci. 26, 103-126.

Keibel, F., 1900: Keibels Normentapfeln zur Entwicklungsgeschichte der Wirbeltiere. Jena: Fischer.

Kernan, J. D., 1916: The development of the occipital region of the domestic cat with an interpretation of the paracondyloid process. Anat. Rec. 10, 213.

Knospe, C., 1996: Die Entwicklung der Magendrüsen der Katze (Felis silvestris catus). Anat. Histol. Embryol. 25, 75-94.

Knospe, C., and G. Böhme, 1995: Zur prenatalen Entwicklung der Glandula mandibularis und Glandula parotis der Katze. Anat. Histol. Embryol. 24, 1-6.

Knospe, C., and J. Plendl, 1997: Histochemical demonstration of lipase activity in the gastric mucosa of the cat. Anat. Histol. Embryol. 26, 303-304.

Krölling, H. B., 1927: Entwicklung, Bau und biologische Bedeutung der Analbeuteldrüsen bei der Katze. Zschr. Anat. Entw.Gesch. 82, 22-69.

Krüger, W., 1929: Die vergleichende Entwicklungsgeschichte im Dienste der Lösung des Homologisierungsproblems an den Darmund Gekröseabschnitten des Menschen und einiger Haussäugetiere (Hund, Katze, Pferd, Schwein und Wiederkäuer). Habilschr. Zschr. Anat. Entwicklgesch. 90, 448-458.

Künzel, E., 1976: Die Problematik der Zuordnung des Geschlechts bei neugeborenen Katzen. Berl. Münch. Tierärztl. Wschr. 89, 366.

Künzel, K., and G. Böhme, 1981: Ein Beitrag zur Entwicklung der Plexus chorioidei. Verh. Anat. Ges. 75, 851-852.

Künzel, E., and C. Knospe, 1986: Zur Entwicklung der Lippendrüse bei der Katze. Ein Beitrag Zur Altersbestimmung. Berl. Münch. Tierärztl. Wschr. 99, 153-156.

Latimer, H. B., 1931: The prenatal growth of the cat. II. The growth of the dimensions of the head and trunk. Anat. Rec. 50, 311-332.

Latimer, R., 1933: The prenatal growth of the cat. III. The growth in length of the two extremities and of their parts. Anat. Rec. 55, 377394.

Latimer, H. B., 1934a: The prenatal growth of the cat. IV. Growth in length and weight of the digestive tube. Anat. Rec. 60, 23-41.

Latimer, H. B., 1934b: The prenatal growth of the cat. V. The ponderal growth of the liver and pancreas. Scritti Biologici 9, 313-322.

Latimer, H. B., 1935: The prenatal growth of the cat. VI. Changes in the relative proportions. Uni. Kansas Sc. Bull. 22, 61-77.

Latimer, H. B., 1938: The prenatal growth of the cat. VII. The growth of the brain and its parts, of the spinal cord and of the eyeballs. J. Comp. Neurol. 68, 381-394.

Latimer, H. B., 1939a: The prenatal growth of the cat. VIII. The weights of the kidneys, bladder, gonads and uterus, with weights of the adult organs. Growth 3, 90-108.
Latimer, H. B., 1939b: The prenatal growth of the cat. IX. The ponderal growth of the hypophysis, thyroid, thymus and suprarenal glands. Growth 3, 337-346.

Latimer, H. B., 1940: The prenatal growth of the cat. X. The weight of the spleen in the fetal period and in the adult. Growth 4, 259-265.

Latimer, H. B., 1941: The prenatal growth of the cat. XI. The weight of the integument in the fetus and in the adult cat. Growth 5, 285-292.

Latimer, H. B., 1942: The prenatal growth of the cat. XII. The weight of the heart in the fetal and in the adult cat. Growth 6, 341-349.

Latimer, H. B., 1943: The prenatal growth of the cat. XIII. The weights of the lungs, trachea, and larynx in the fetal and in the adult cat. Growth 7, 239-250.

Latimer, H. B., 1944a: The prenatal growth of the cat. XIV. The weight of the skeleton in the fetal and in the adult cat. Growth $\mathbf{8}$, 149-158.

Latimer, H. B., 1944b: The prenatal growth of the cat. XV. The weight of the musculature in the fetal and in the adult cat. Growth 8, 205219.

Latimer, H. B., 1948: The prenatal growth of the cat. XVI. The changes in the relative weights of the organs. Growth 12, 123-144.

Leiser, C. B., 1979: Blastozystenimplantation bei der Hauskatze. Lichtund Elektronenmikroskopische Untersuchungen. Zbl. Vet. Med. C 8, 79-96.

Ling, T. L., and J. Stone, 1988: The development of astrocytes in the cat retina: evidence of migration from the optic nerve. Brain Res. Dev. Brain Res. 44, 73-85.

Lolova, I., 1983: Ontogenesis of the myenteric plexus in the cat gastrointestinal sphincters. I. Development of the neural perikarya and dendrites; II. Axonal differentiation; III. Synaptogenesis. Z. Mikrosk. Anat. Forsch. 97, 441-462; 463-479; 597-614.

Lolova, I., and D. Itsev, 1983: Prenatal development of the myenteric plexus in cat stomach. Acta Physiol. Pharmacol. Bulg. 9 (4), 63-73.

Longley, W. H., 1911: The maturation of the egg and ovulation in the domestic cat. Am. J. Anat. 12, 139-172.

Manwell, E. J., and P. G. Wickens, 1928: The mechanism of ovulation and implantation in the domestic cat. Anat. Rec. 38 (Suppl. 54).

Martin, P., 1890a: Zur Entwicklung der Retina der Katze. Anat. Anz. 5, 551-556.

Martin, P., 1890b: Die erste Entwicklung der Kopfnerven bei der Katze. Österr. Mschr. Tierheilk. 337-363.

Martin, P., 1890c: Zur Entwicklung der kavernösen Körper des Penis und der Harnröhre bei der Katze. Deut. Zschr. Tiermed. vergl. Pathol. 16, 133-136.

Martin, P., 1891a: Die Entwicklung des neunten bis zwölften Kopfnerven bei der Katze. Anat. Anz. 6, 228-232.

Martin, P., 1891b: Zur Entwicklung der Netzhaut bei der Katze. Zschr. vergl. Augenheilk. 7.

Martin, P., 1894a: Zur Entwicklung des Gehirnbalkens bei der Katze. Anat. Anz. 9, 5-6.

Martin, P., 1894b: Bogenfurche und Balkenenntwicklung bei der Katze. Inaugural-Diss. Phil. Fakultät Zürich.

Martin, P., 1895: Zur Entwicklung der Gehirnfurchen bei Katze und Rind. Arch. Wiss. Prakt. Tierheilk. 21, 1-16.

McLaren, A., 1978: Der Embryo. In: Fortpflanzungsbiologie der Säugetiere. Bd.2 Embryonale und fötale Entwicklung (C. R. Austin and R. V. Short, eds.). Berlin, Hamburg: P. Parey, pp. 9-39.

McLaren, A., 1980: Fertilization, Cleavage and Implantation. In: Reproduction in Farm Animals 4th edn. (E. S. E. Hafez, ed.). Philadelphia: Lea and Febiger, pp. 226-246.

Murray, G., 1951: The mechanism of attachment of the blastocyst in the cat. J. Anat. 85, 431-434.

Nelson, N. S., and J. Cooper, 1975: The growing conceptus of the domestic cat. Growth 39, 435-451.

Nishimura, H., K. Takano, T. Tanimura, and M. Yasuda, 1968 Normal and abnormal development of human embryos, first report of the analysis of 1.213 intact embryos. Teratology 1, 281-290. 
Noden, D. M., and A. DeLahunta, 1985: The Embryology of Domestic Animals. Baltimore: Williams \& Wilkins.

Oppel, A., 1891: Vergleichung des Entwicklungsgrades der Organe zu verschiedenen Entwicklungszeiten bei Wirbeltieren. Jena, Fischer.

Otis, E. M., and R. Brent, 1954: Equivalent ages in mouse and human embryos. Anat. Rec. 120, 33-63.

Phemister, R. D., 1974: Nonneurogenic reproductive failure in the bitch. Vet. Clin. North Am. 4, 573-586.

Pope, C. E., G. L. Keller, and B. L. Dresser, 1993: In-vitro fertilization in domestic and nondomestic cats including sequences of early nuclear events, development in vitro, cryopreservation and successful intraspecies and interspecies embryo-transfer. J. Reprod. Fert. Suppl. 47, 189-201.

Ramoa, A. S., G. Campbell, and C. J. Shatz, 1988: Dendritic growth and remodeling of cat retinal ganglion cells during fetal and postnatal development. J. Neurosci. 8 (11), 4239-4261.

Rapaport, D. H., and J. Stone, 1983: The topography of cytogenesis in the developing retina of the cat. J. Neurosci. 3, 1824-1834.

Rojas, M. A., and M. A. Montenegro, 1995: An anatomical and embryological study of the clavicle in cats (Felis domestus) and sheep (Ovis aries) during the prenatal period. Acta Anat. 154, 128-134.

Romand, R., A. Sans, M. R. Romand, and R. Marty, 1976: The structural maturation of the stato-acoustic nerve in the cat. J. Comp. Neurol. 170, 1-15.

Root, M. V., S. D. Johnston, and P. N. Olson, 1995: Estrous length, pregnancy rate, gestation and parturition lengths, litter size and juvenile mortality in the domestic cat. J. Am. Anim. Hosp. Assoc. 31, 429-433.

Rüsse, I., and F. Sinowatz, 1991: Lehrbuch der Embryologie der Haustiere. Berlin, Hamburg: P. Parey.

Sainmont, H., 1906: Recherches relatives à l'organogenèse du testicule et de l'ovaire chez le chat. Arch. Biol. 22, 71-162.

Schaeffer, A. C., 1932: Ossifikationsvorgänge im Gliedmaßenskelett der Hauskatze. Morph. Jb. 70, 548-600.

Schnorr, B., 1989: Embryologie der Haustiere. 2. Aufl. Stuttgart: Enke. Schulte, H. von W., 1916: The fusion of the cardiac anlages and the formation of the cardiac loop in the cat (Felis domestica). Am. J. Anat. 20, 45-72.

Schwarz, R., 1987: zur Morphogenese des Sinus paranalis der Katze. Anat. Histol. Embryol. 16, 325-329.

Schwarz, R., M. R. Fath El-Bab, and H. Wissdorf, 1983: Analbeutel und Analbeuteldrüsen der Katze. I. Zur Histomorphologie ihrer Entwicklung. Effem Report 18, 5-12.

Schwarz, R., M. R. Fath El-Bab, and H. Wissdorf, 1984: Analbeutel und Analbeuteldrüsen der Katze. II. Vergleichende Untersuchung zur Entwicklung von Analbeutel und äußerer Haut. Effem Report 18, 25-31.

Scott, P. P., 1977: The cat as an experimental animal. Proc. R. S. Med. 70, 1-3.

Sivachelvan, M. N., M. G. Ali, and G. A. Chibuzo, 1996: Fetal Age Estimation in Sheep and Goats. Small Ruminant Research 19 (1), 69-76.

Stedman, H., C. M. Mistretta, and R. M. Bradley, 1983: A quantitative study of cat epiglottal taste buds during development. J. Anat. 136, 821-827.

Swanson, W. F., T. L. Roth, and D. E. Wildt, 1994: In vivo embryogenesis, embryo migration, and embryonic mortality in the domestic cat. Biol. Reprod. 51 (3), 452-464.

Takaya, A., 1989: A study on superovulation and embryo development in the domestic cat. Jap. J. Vet. Res. 37, 132.

Terry, R. J., 1917: The primordial cranium of the cat. J. Morph. 29, 281-433.
Teske, B., 1986: Die Entwicklung der Milchdrüse beim Kater. Vet. Med. Diss. Berlin.

Tichy, F., 1993: The morphogenesis of circumvallate papillae and the differentiation of taste buds in the cat in ontogeny. Acta Vet. Brno 62 (1-2), 19-26.

Tiedemann, K., 1976a: On the yolk sac of the cat. Cell Tiss. Res. 173, 109-127.

Tiedemann, K., 1976b: The mesonephros of cat and sheep. Comparative morphological and histochemical studies. Adv. Anat. Embryol. Cell Biol. 52, 1-117.

Tiedemann, K., and B. van Ooyen, 1978: Prenatal haematopoiesis and blood characteristics of the cat. Anat. Embryol. 153, 243-267.

Timm, S., 1987a: Zur Morphologie und Entwicklung des Craniums von Felis silvestris f. catus LINNÉ 1758 -ein Beitrag zur vergleichenden Anatomie der Carnivora, Teil I: Einleitung, Material und Methoden, Gesamtes Cranium und Regio ethmoidalis. Gegenb Morphol. Jahrb 133, 411-467.

Timm, S., 1987b: Zur Morphologie und Entwicklung des Craniums von Felis silvestris f. catus LINNÉ 1758 -ein Beitrag zur vergleichenden Anatomie der Carnivora, Teil II: Regio orbitotemporalis. Gegenb. Morphol. Jahrb 133, 605-637.

Timm, S., 1987c: Zur Morphologie und Entwicklung des Craniums von Felis silvestris f. catus LINNÉ 1758 -ein Beitrag zur vergleichenden Anatomie der Carnivora, Teil III: Regio otica, Regio occipitalis. Gegenb. Morphol. Jahrb 133, 687-729.

Timm, S., 1987d: Zur Morphologie und Entwicklung des Craniums von Felis silvestris f. catus LINNÉ 1758 -ein Beitrag zur vergleichenden Anatomie der Carnivora, Teil IV: Visceralskelet, Deckknochen; Zusammenfassung und Folgerungen. Gegenb. Morphol. Jahrb 133, 793-835.

Trnkova-Hergetova, E., and I. Dylevsky, 1994: Musculi contrahentes in the ontogensis of the cat limb. Funct. Dev. Morphol. 4, 109-112.

Turner, C. W., and W. R. DeMoss, 1934: The normal and experimental development of the mammary gland. I. The male and female domestic cat. Mo Agr. Exp. Sta. Res. Bull. 207, 4-15.

van Ooyen, B., 1977: Blutbildung und Blutbild beim Katzenembryo. Vet. med. Diss. Berlin.

Vanlommel, A. T. L., and J. M. Lauweryns, 1993: Ultrastructure and innervation of neuroepithelial bodies in the lungs of newborn cats. Anat. Rec. 236, 181-190.

Velicky, J., and M. Titlbach, 1986: Cytodifferentiation of the thyroid tissue of the cat (Felis catus L.) during prenatal development. I The follicular epithelium. Z. Mikroskop. Anat. Forsch. 100, 353-371.

von Kobyletzki, D. J., and O. Gellen, 1970: Zur Vorhersage des embryonalen Entwicklungszustandes beim Menschen. Arch. Gynäkol. 209, 293-304.

Wildt, D. E., J. L. Brown, and W. F. Swanson, 1998: Cats. In: Encyclopedia of Reproduction, Vol. 1 (E. Knobil, and J. D. Neill, eds). New York: Academic Press, pp. 497-510.

Windle, W. F., and A. M. Griffin, 1931: Observations on embryonic and fetal movements of the cat. J. Comp. Neurol. 52, 149-188.

Wöhrmann-Repenning, A., 1989a: Beobachtungen zur frühen Entwicklung des Jacobsonschen Organs der Katze (Felis silvestris) Gegenb. Morph. Jahrb. 135 (5), 765-773.

Wöhrmann-Repenning, A., 1989b: Zur spätembryonalen Entwicklung des Vomeronasalkomplexes der Katze (Felis silvestris). Gegenb. Morph. Jahrb. 135 (6), 917-927.

Yamamura, H., 1969: Individuelle Unterschiede des Entwicklungszustandes bei Embryonen der Maus (C57BL) in der frühen Phase der Organogenese. W. Roux' Arch. 162, 218-242.

Zietzschmann-Krölling, O., 1955: Lehrbuch der Entwicklungsgeschichte der Haustiere. 2. Aufl. Berlin, Hamburg: P. Parey. 